\title{
At begribe det uhåndgribelige - og beskytte det
}

Konference om den immaterielle kulturarv 8. december 2005, Det Kongelige Bibliotek, København

\author{
MAds DAugbJerg
}

UNESC0-konventionen fra 2003 om beskyttelse af verdens immaterielle kulturarv står foran en eventuel ratificering i Danmark. Men hvad skal man overhovedet forstå ved begrebet 'immateriel kulturarv', som udvider det $i$ forvejen vagt definerede kulturarvsbegreb, og giver det mening at ville sikre og beskytte den immaterielle arv på linje med den fysiske? Konferencen afholdt i København i december 2005 søgte at reflektere over nogle grundlæggende, opklarende spørgsmål til den nye konvention i form af oplæg fra en række kulturforskere.

I 2003 fremlagde UNESCO, efter mange års tilløb og forhandlinger, sin Convention for the Safeguarding of the Intangible Cultural Heritage (UNESCO 2003). Konventionen er en lillebror til sin mere kendte forgænger fra 1972, der fokuserer på beskyttelse af verdens materielle kulturarv, og er især et resultat af tredjeverdenslandes pres for anerkendelse i UNESCO. Den udtalte overrepræsentation af vestlig og europæisk kultur, som karakteriserer 1972konventionen og den deraf afledte liste over World Heritage Sites, ${ }^{1}$ har længe affødt kritik fra stater, som ikke kan bryste sig af markante materielle levn. Groft sagt vil den tredje verden også have en bid af den kulturelle kage ikke mindst fordi den opmærksomhed og prestige, som følger i kølvandet på en UNESCO- blåstempling af et stykke verdenskulturarv, kan have både politisk og økonomisk værdi (Timothy \& Boyd 2003: 115; Hitchcock 2002; Kirshenblatt-Gimblett 2004: 61).

Det skal fremhæves, at en del af kritikken mod især 1972-konventionens problematiske definitioner har haft form af selvkritik fra UNESCOS interne komiteer. De fortløbende revisioner af retningslinjerne for implementeringen af konventionen ${ }^{2}$ demonstrerer en stadig mere udviklet følsomhed i UNESCO over for mindre monumentale kulturelle udtryk. Derfor må den nye konvention til beskyttelse af den immaterielle arv betragtes ikke bare som et krav fra den sydlige halvkugle om anerkendelse af kulturel ligeværdighed med de 'gamle' vestlige nationer - som naturligvis i 
mange tilfælde er tidligere kolonimagter men også som resultatet af en glidende og vedblivende intern proces i UNESCO. ${ }^{3}$ Den nye konvention hviler så at sige på en usagt men slet skjult ambition om at genskabe en form for global kulturel balance og må vurderes på baggrund af globale geopolitiske relationer mellem staterne, herunder problematiske postkoloniale forhold mellem 'Vesten' og 'Resten'.

Konventionen definerer immateriel kultur$\operatorname{arv}^{4}$ som følger:

The "intangible cultural heritage" means the practices, representations, expressions, knowledge, skills

- as well as the instruments, objects, artefacts and cultural spaces associated therewith - that communities, groups and, in some cases, individuals recognize as part of their cultural heritage. (UNESCO 2003: \$1)

En sådan ekstremt bred definition af den immaterielle arv, som altså angiveligt kan identificeres helt ned på individplan - de udtryk og den viden, som det enkelte menneske betragter som sin kulturelle bagage - synes at frembyde omfattende prioriterings- og afgrænsningsmæssige problemer, hvis den skal omsættes til en anvendelig praksis. Til støtte for dette arbejde identificerer konventionen fem "domæner, hvori den immaterielle arv 'manifesteres" (ibid.: \$2):

(a) oral traditions and expressions, including language as a vehicle of the intangible cultural heritage;

(b) performing arts;

(c) social practices, rituals and festive events;

(d) knowledge and practices concerning nature and the universe;

(e) traditional craftsmanship.

Inden man indlader sig på væsentlige og vanskelige spørgsmål om, hvad man i givet fald skal vælge, hvem der skal vælge, og på hvis vegne, kan det imidlertid være umagen værd at rejse nogle mere grundlæggende, kritiske spørgsmål til selve UNESCO-konventionen og de grundantagelser og kulturforståelser, den hviler på - og det er præcist, hvad konferencen i København sigtede mod.

\section{KONFERENCENS BAGGRUND: BASALE BE- TÆNKELIGHEDER}

Kulturministeriets Forskningsudvalg var initiativtager til den velbesøgte konference i det Kgl. Bibliotek i København. Som udvalgsformand, professor Kirsten Hastrup, skrev i det oplæg, som fulgte indbydelsen, fandt udvalget det "formålstjenstligt at diskutere selve begrebet immateriel kulturarv forud for en eventuel implementering af konventionen i Danmark" (Hastrup 2005). Man ville til roden af begrebet, ikke mindst fordi Forskningsudvalget i UNESCOs materiale sporer "en slagside i retning af det folkloristiske, som måske er uhensigtsmæssig" (ibid.) ${ }^{5}$. Og videre hedder det, at UNESCO synes at opretholde

en implicit, og betænkelig forstålse af, at hvor Vesten har store historiske monumenter og skriftlighed, så har Resten dans og mundtlighed - som skal beskyttes på lige fod. Det er derfor en udfordring at skabe en forståelse af den immaterielle kulturarv, der kan bruges på tværs af kulturer, om man vil. (ibid.)

Konventionens ubetvivleligt gode hensigter hviler ifølge Forskningsudvalget på en problematisk forståelse af selve kulturarvsbegrebet, som i udvalgets øjne peger mod "en utidssvarende forestilling om national kultur og homogenitet, som ikke afspejler verdens faktiske tilstand" (ibid.). Over for en sådan kritik 
kan man indvende, at den negligerer den vedblivende interne refleksion i UNESCO, som allerede er omtalt, og som har resulteret i en række initiativer og publikationer, der netop søger at overskride lighedstegnet mellem nation og kulturarv og at promovere multikulturalisme som en resurse. ${ }^{6}$ Antagelsen om et 1:1forhold mellem nation og kulturarv, som Forskningsudvalget tillægger UNESCO, synes med andre ord at være misvisende i forhold til UNESCOs faktiske arbejde. Men organisationens opfordringer til accept og beskyttelse af minoritetsgruppers rettigheder ændrer naturligvis ikke på, at det er op til staterne selv suverænt at definere og forvalte deres kulturelle arv.

Som alternativ til det, Forskningsudvalget altså betragter som UNESCOs folkloristiske og nationalbundne begreb om immateriel kulturarv, satte konferencen fokus på tre dimensioner af det immaterielle kulturelle liv i Danmark, som - stadig ifølge udvalgsformanden "skaber væsentlig sammenhæng i samfundet ved at aktivere fælles erfaringer og erindringer, men som ikke nødvendigvis er knyttet til 'det nationale' i romantisk forstand" (ibid.). Det drejer sig om den performative, den sproglige og den kundskabsmassige dimension. Under disse tre overskrifter gav konferencen ordet til seks forskere, som kom med bud på en facetteret forståelse af den immaterielle kulturarv i en dansk kontekst.

\section{KULTURENS FLYGTIGHED SOM HOVEDTEMA}

"Egentlig er al kulturarv immateriel". Med de ord understregede sprogforsker og direktør for Det danske Sprog- og Litteraturselskab Jørn Lund, en af dagens oplægsholdere, at det materielle og det immaterielle er to sider af sam- me sag. Pantheon og Colloseum er jo materielt set blot livløse sten og ruiner, som kræver menneskelig - immateriel - betydningstilskrivning for at blive til (verdens-) kulturarv. Det immaterielle aspekt ligger med andre ord allerede mellem linjerne i 1972-konventionen om den materielle arv, og al kategorisering af kulturarv er altid et produkt af menneskers handlinger og valg. Det er en pointe, som i al sin enkelhed er nem at overse, når man læser UNESCOs 1972-konvention, som efterlader et indtryk af en serie storslåede fortidslevn med iboende egenskaber, som slumrende ligger hen og venter på at blive gravet op eller støvet af og komme til deres naturgivne ret. ${ }^{7}$

Denne nøglepointe fungerede for Lund som optakt til hans oplæg om sproget som kulturel og immateriel lim for fællesskaber af både national og lokal art. Imidlertid var en af hans gennemgående pointer, at sprog og ord netop - ligesom al anden kulturarv, som påpeget ovenfor - opstår, defineres og videregives i praksis i henhold til menneskers brug og behov. Ord er med hans udtryk "kulturens gesandter”, rejsende på tværs af grænser og samfund, og strømmen af låneord følger som regel de stærke: mens det danske sprog i øjeblikket især udsættes for påvirkninger fra den engelsktalende verden og i særdeleshed USA, er det i et længere tidsperspektiv i langt højere grad modelleret over tysk. Med morsomme anekdoter og eksempler på låneordenes dominans i dansk sprogbrug efterlod Lund ingen tvivl om hovedbudskabet: at sprog fungerer på markedsbetingelser, og at man muligvis kan begræde udviklingen og de uddøende dialekter der dør to sprog om måneden på verdensplan - men at det ikke giver nogen mening at ville holde dem kunstigt i live eller sikre dem på anden måde end ved at dokumentere dem grundigt. 
På parallel vis forholdt en række af dagens øvrige oplægsholdere sig til samme grundtema: at immaterielle kulturelle omgangsformer - det være sig sprog, vandrehistorier, dyrkningskultur, normer for fællesskabsdyrkelse, eller noget femte - lever, omformes og uddør under konstant påvirkning fra ikke-nationale kræfter og dagsordener. Eksempelvis opridsede Else Marie Kofoed, seniorforsker ved Dansk Folkemindesamling, hvordan danske eventyr og fortællinger for langt hovedpartens vedkommende er lokale, tilpassede versioner af grundfortællinger, som under kontinuerlige genforhandlinger har rejst over lange geografiske afstande. Det gælder ikke kun mundtligt overleverede vandrehistorier, men også velkendte eventyr fra kanoniserede klenodier, fx H. C. Andersens 'Hvad fatter gør, er altid det rigtige'. Malene Hauxner, professor ved den Kgl. Veterinær- og Landbohøjskole i København, påpegede tilsvarende $\mathrm{i}$ sit oplæg om dyrkningskulturens sprog i Danmark, hvordan internationale strømninger og landskabsopfattelser har sat deres grundige aftryk på danske diskurser om landskabets og det dyrkede lands karakter og udvikling.

Konferencedeltagernes gennemgående understregning af de kulturelle formers flydende karakter og evindelige omkalfatring i henhold til lokale, nutidige behov, er i og for sig ikke revolutionerende. I hvert fald siden de britiske historikere Hobsbawm \& Ranger i 1983 udgav deres indflydelsesrige bog The Invention of Tradition, har det været gængs akademisk tone at betragte 'traditioner' og 'kulturer' som, om ikke opfundne, så i hvert fald kontinuerligt (og ind imellem opfindsomt) genforhandlede konstruktioner. Når det alligevel er værd at tage den tråd op igen, er det netop fordi den foreliggende UNESCO-konvention ikke synes at operere med samme syn på kultur og nation. Og fordi organisationens velmente anstrengelser til sikring af de nationalt definerede og nationalt forvaltede immaterielle kulturudtryk forekommer at skurre mod den akademiske opfattelse af kulturens flygtighed. Med udvalgsformand Hastrups ord kan man spørge, "hvorvidt det overhovedet er hensigtsmæssigt at udstrække kulturarvsbegrebet til også at omfatte immaterielle forhold, som i deres natur må være både bevægelige, flertydige og flygtige" (Hastrup 2005).

\section{OG HVAD SÅ? ANSATSER TIL EN VIDERE DISKUSSION}

Der var altså ikke tale om nye teoretiske landvindinger, når det under konferencen påpegedes, at immaterielle kulturformer og fællesskaber konstant er under konstruktion. Men det er værd at diskutere, hvordan et sådant grundlæggende konstruktivistisk kultursyn kan sameksistere med UNESCOs arbejde, som forekommer at sigte mod en sikring og objektivisering af immaterielle kulturformer - og hvordan man skal analysere og forstå dette tilsyneladende behov for at fastholde og værdisætte uhåndgribelige udtryk.

I dagens sidste oplæg leverede Karen Lisa Salamon, lektor ved Danmarks Designskole, ansatser til en sådan fremadrettet diskussion i form af en kritisk analyse af relationen mellem kulturliv og erhvervsliv. Hun hæftede sig især ved, hvordan kultursektoren i stigende grad måles og vurderes på kommercielle vilkår, og hvordan markedsterminologi bliver det internationale sprog i en globaliseret verden. Både materielle og immaterielle produkter objektiviseres og værdisættes ved hjælp af kommercielle mekanismer, og et af nøgleordene i den forbindelse er rettigheder. Salamon gav eksemp- 
ler på, hvordan trademarketing, eller blot TM'ing - de to små bogstaver i hjørnet af alverdens logoer - for længst er blevet hæftet på en lang række immaterielle produkter og ydelser. Hotelkæden Holiday Inn tilbyder for eksempel konceptet Forget something TM, som angiveligt består af en art garanti for at hotelgæsterne kan afhente en ny tandbørste eller en anden dingenot, de måtte have glemt derhjemme, i hotellets reception. Holiday Inn har altså sikret sig rettighederne til denne immaterielle serviceydelse, ligesom popstjernen Britney Spears på sit seneste album har sikret sine rettigheder ved simpelthen at optræde som Britney ${ }^{\mathrm{TM}}$.

Trademarketing og spørgsmål om ophavsret har for længst forladt den rent kommercielle sfære og er blevet centrale redskaber overalt i Vesten, også i den kulturelle sektor. I kulturarvsøjemed gælder det naturligvis ikke mindst i stridigheder om repatriering af genstande, altså af den materielle kulturarv. Men det gælder også i mere uhåndgribelige tvister om indfødte gruppers autenticitet - og dermed deres rettigheder, fx til at markedsføre deres kunsthåndværk som 'indfødt kunst', eller til at kræve 'indfødt' land tilbage. Hvilke (immaterielle) kvaliteter kræves for at tælle som indianer, og hvilke kriterier måles man på, når man hævder at tilhøre en 'stamme'?8

Udviklingen går altså ifølge Salamon i retning af, at det uhåndgribelige gøres håndgribeligt, måleligt og regulerbart i henhold til kommercielle og juridiske mekanismer. Hendes analyse sætter på overbevisende vis UNESCOs anstrengelser for at sikre og værdisætte den immaterielle kulturarv i perspektiv. Et perspektiv, som demonstrerer, hvordan det internationalt set er den økonomisk-juridiske diskurs, som hersker - og også sætter dagsordenen i kultursektoren.
Afrunding: ET FLIMRENDE SLUTBILLEDE

Konferencens oplægsholdere gav en række meget forskelligartede bud på, hvorfor immateriel kulturarv kan forstås som meget andet end de folkloristiske udtryk, som udødeligg $\varnothing$ res på UNESCOs lister. Men trods de mange interessante pointer og analyser fremstod konferencens facit samlet set noget flimrende, ikke mindst fordi UNESCO-konventionen som sådan var stort set fraværende.

Oplægsholderne var ikke blevet bedt om at forholde sig hverken til konventionen eller til de interessante, kritiske grundspørgsmål til konventionen, som Forskningsudvalget havde formuleret (Hastrups skriftlige opdrag, refereret indledningsvist). Ordet var $\mathrm{i}$ stedet givet frit til at reflektere over, hvordan immaterielle kulturformer i bred forstand skaber fællesskaber og vedligeholdes eller ændres over tid. Resultatet var, at det - udover de overordnede pointer om kulturens processuelle og foranderlige karakter - var vanskeligt at identificere en rød tråd. Og kun på et meget abstrakt plan kunne oplæggene siges at kommentere UNESCOs konkrete initiativer, som flere af oplægsholderne tydeligvis slet ikke var bekendt med.

Forskningsudvalgets interessante og relevante - men også til en vis grad forsimplede kritik af UNESCO forblev derfor desværre langt hen ad vejen ubehandlet, simpelthen fordi oplægsholderne ikke forholdt sig til den. Man savnede én med indsigt eller mod til at gå i kødet på selve konventionen, eller én, som havde orienteret sig i den litteratur, som er fulgt i kølvandet på den. ${ }^{9}$ Eller måske blot, at de seks oplægsholdere havde fået stillet, som en del af deres opgave, at diskutere udvalgets kritiske oplæg set fra deres respektive ståsteder.

Som de fremstod på dagen, bidrog oplæg- 
110 gene mest til at fremhæve, at kultur og kulturarv skam er mangt og meget, og at UNESCO derfor ikke har monopol på definitionerne. Og det vidste vi vel egentlig godt, især hvis vi havde læst Forskningsudvalgets oplæg. Det er i den forbindelse i øvrigt bemærkelsesværdigt, og måske sigende, at tre af de indbudte oplægsholdere var antropologer, ligesom udvalgsformanden selv. Konferencens hovedbudskab kan i det lys, lidt fortættet og måske forsimplet, siges at være en antropologisk kritik af et arkæologisk funderet kulturbegreb, som i antropologernes øjne ureflekteret søges overført fra de fysiske levn til de immaterielle udtryk.

Konferencens værter har ikke desto mindre stor ære af deres initiativ. Det er sjældent, det lykkes at sætte nogle af de grundlæggende automatpiloter og ureflekterede antagelser under kulturarvssektoren til diskussion. Det lykkedes ganske vist heller ikke til fulde denne gang, men forsøget blev gjort, og det bliver forhåbentlig gjort igen. Og næste gang gerne, så vi som tilhørere bliver klogere på den konkrete konvention og de implikationer, en eventuel dansk ratifikation vil have. $\mathrm{Nu}$ ved vi, immateriel kulturarv er mange ting. Det næste vi gerne vil vide, er om det, som UNESCO hævder er immateriel kulturarv, kunne være værd at sikre - og i givet fald hvordan man gør det.

\section{NOTER}

1. Eksempelvis kan Frankrig, Italien og Spanien tilsammen frembyde mere 'verdenskulturarv' end hele det afrikanske kontinent. Se hele listen på http://whc.unesco.org/en/list .

2. For disse retningslinjer, som senest er opdateret februar 2005, se: http://unesdoc.unesco.org/images/0013/001386/138676e.pdf

3. For en detaljeret gennemgang af forløbet, som førte frem til 2003-konventionen, se Bouchenaki 2004; Munjeri 2004; Kurin 2004.

4. Begrebet 'immateriel kulturarv' anvendes i denne artikel, ligesom på konferencen i København, som direkte oversættelse af konventionens engelske term 'intangible cultural heritage'.

5. De eksempler på immateriel arv, som UNESCO på sin hjemmeside fremhæver som 'Masterpieces of the Oral and Intangible Heritage of Humanity' - en liste, som kan anskues som en art forløber for den nye konvention - har især vægt på 'traditionelle' danse, sange, ritualer og håndværk. Se listen på http://www.unesco.org/culture/intangible-heritage/mastlist_en.htm .

6. Se især den indflydelsesrige rapport Our Creative Diversity fra 1995 på: http://unesdoc.unesco.org/images/0010/001055/105586e.pdf .

7. For uddybninger af denne pointe - at 'kulturarven' produceres af mennesker i henhold til nutidige behov - se fx Handler 1985; Lowenthal 1994; McCrone et al. 1995; Handler \& Gable 1997; Kirshenblatt-Gimblett 1998.

8. For en grundig analyse af en specifik amerikansk retssag om retten til 'indfødt' land, se Clifford 1988. For en juridisk baseret diskussion af den nye konvention og spørgsmål om rettigheder og ejerskab, se Wendland 2004.

9. Se især et særnummer af tidsskriftet Museum International (Bouchenaki (ed.) 2004), hvori konventionens ambitioner, grundlag og dilemmaer tages under kyndig og kritisk behandling $\mathrm{i}$ en lang række artikler. 


\section{LITTERATUR}

Bouchenaki, M.: 'Editorial'. Museum International. Vol. 56. No. 1-2. 2004, s. 6-10.

Clifford, J.: 'Identity in Maspee', s. 277-346, in The Predicament of Culture. Twentieth Century Ethnography, Literature, and Art. Harvard University Press: Cambridge, Massachusetts 1988.

Handler, R.: 'On having a Culture. Nationalism and the preservation of Quebec's Patrimoine', s. 192215 in Stocking G. W. (ed.) Objects and Others. Essays on Museums and Material Culture. University of Wisconsin Press: Wisconsin 1983.

Handler, R. \& E. Gable: The New History in an Old Museum. Creating the Past at Colonial Williamsburg. Duke University Press, Durham and London 1997.

Hastrup, K.: 'Konference om den immaterielle kulturarv'. 2005. Oplæg til konferencen, som kan findes på: http://www.kum.dk/graphics/kum/downloads/K ulturomraader/Kulturbevaring/Kulturarvskonference\%20beskrivelse.doc

Hitchcock, M.: 'Zanzibar Stone Town joins the Imagined Community of World Heritage Sites'. International Journal of Heritage Studies. Vol. 8, No. 2. 2002, s. 153-166.

Hobsbawm, E. \& T. Ranger (eds): The Invention of Tradition. Cambridge University Press: Cambridge 1983.

Kirshenblatt-Gimblett, B.: 'Destination Museum', pp. 131-176 in Destination Culture. Tourism, Museums, and Heritage. University of California Press: Berkeley 1998.

Kirshenblatt-Gimblett, B.: 'Intangible Heritage as Metacultural Production'.Museum International. Vol. 56. No. 1-2, 2004, s. 52-65.

Kurin, R: 'Safeguarding Intangible Cultural Heritage in the 2003 UNESCO Convention: a critical appraisal'. Museum International. Vol. 56. No. 1-2. 2004, s. 66-77.
Lowenthal, D.: 'Identity, Heritage, and History', pp. 41-57 in Gillis, J. R. (ed.): Commemorations. The Politics of National Identity. Princeton University Press: Princeton 1994.

McCrone, D., A. Morris \& R. Kiely: Scotland - the Brand. The Making of Scottish Heritage. Edinburgh University Press, Edinburgh 1995.

Munjeri, D.: 'Tangible and Intangible Heritage: from difference to convergence'. Museum International. Vol. 56. No. 1-2, 2004, s. 12-20.

Timothy, D. J. \& S. W. Boyd: Heritage Tourism. Prentice Hall: Harlow, England 2003.

UNESCO: Convention for the Safeguarding of the Intangible Cultural Heritage. http://unesdoc.unesco.org/images/0013/001325/132540e.pdf . Paris 2003

UNESCO: Convention Concerning the Protection of the World Cultural and Natural Heritage. http://whc.unesco.org/archive/convention-en.pdf . Paris 1972.

Wendland, W.: 'Intangible heritage and intellectual property: challenges and future prospects'. $\mathrm{Mu}-$ seum International, Vol. 56. No. 1-2, 2004, s. 97-107.

Mads Daugbjerg er mag.art. i Antropologi og etnografi med speciale $i$ turisme og kulturarv. Han har fungeret som ekstern lektor ved forskellige danske universiteter, bl.a. ved Center for Museologi, Aarhus Universitet. Han arbejder for tiden ved Afdeling for Antropologi og Etnografi, Aarbus Universitet, på sin ph.d. med titlen 'Kampen om Dybbol: kulturarv, turisme og identitet på et omstridt sted'.E-mail:maz@e-box.dk. 